\title{
MIRLET7G wt Allele
}

National Cancer Institute

\section{Source}

National Cancer Institute. MIRLET7G wt Allele. NCI Thesaurus. Code C81830.

The human MIRLET 7G wild-type allele is located in the vicinity of 3p21.1 and is 83 bases in length. This allele, which encodes MIRLET7G RNA, plays a role in development of lung and ovarian cancers. 